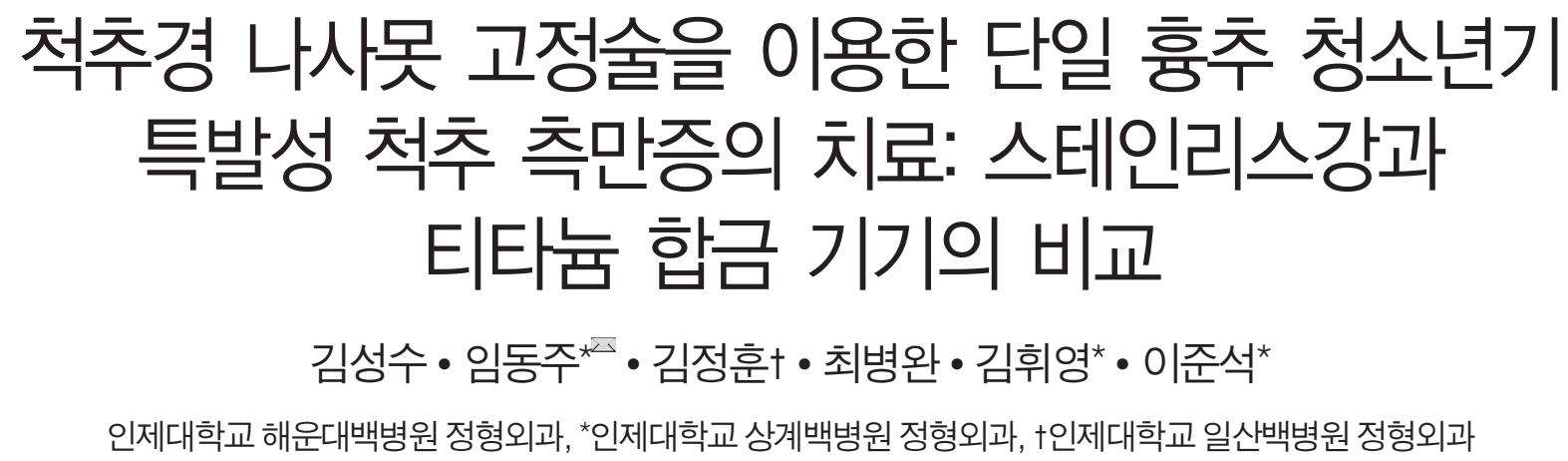

\title{
Correction of Single Thoracic Adolescent Idiopathic Scoliosis Using Pedicle Screw Instrumentation: Comparison of Stainless Steel to Titanium Alloy Instruments
}

\author{
Sung-Soo Kim, M.D., Dong-Ju Lim, M.D.* ${ }^{*}$, Jung-Hoon Kim, M.D.†, Byung-Wan Choi, M.D., \\ Hwi-Young Kim, M.D.*, and Jun-Seok Lee, M.D.* \\ Department of Orthopedic Surgery, Inje University Haeundae Paik Hospital, Busan, ${ }^{\star}$ Department of Orthopedic Surgery, Inje University Sanggye \\ Paik Hospital, Seoul, †Department of Orthopedic Surgery, Inje University Ilsan Paik Hospital, Goyang, Korea
}

Purpose: To compare the results of two different instruments made of stainless steel and titanium alloy for correction of single thoracic adolescent idiopathic scoliosis (AIS) using pedicle screw instrumentation.

Materials and Methods: A total of 141 patients with single thoracic AIS treated with pedicle screw instrumentation and selective thoracic fusion were retrospectively reviewed after a follow-up of 2 years. The patients had a main thoracic curve of $40^{\circ}$ to $75^{\circ}$ and were divided into two groups based on instrument materials; $S$ group (stainless steel, $n=90$ ) and T group (titanium alloy, $n=51$ ). The diameter of the stainless steel rod used was $7.0 \mathrm{~mm}$ while that of the titanium alloy rod was $6.35 \mathrm{~mm}$ or $6.0 \mathrm{~mm}$. Standing long-cassette radiographic measurements including various coronal and sagittal parameters for the preoperative, early postoperative and 2-year postoperative followup were analyzed. There were no significant differences in the preoperative curve characteristics between the two groups.

Results: In the S group, the preoperative main thoracic curve of $51.3^{\circ} \pm 8.4^{\circ}$ was improved to $19.0^{\circ} \pm 7.6^{\circ}(63.1 \%$ correction) and the lumbar curve of $32.3^{\circ} \pm 8.4^{\circ}$ spontaneously decreased to $12.7^{\circ} \pm 8.2^{\circ}(62.9 \%$ correction) at 2 years postoperatively. In the $T$ group, the preoperative main thoracic curve of $49.5^{\circ} \pm 8.4^{\circ}$ and the lumbar curve of $30.3^{\circ} \pm 8.9^{\circ}$ was improved to $18.8^{\circ} \pm 7.4^{\circ}\left(62.2 \%\right.$ correction) and $11.3^{\circ} \pm 5.4^{\circ}\left(63 . \%^{\circ}\right.$ correction), respectively. The corrections of coronal curves were not statistically different between the two groups (p $>0.05)$. The thoracic kyphosis was changed from $16.8^{\circ} \pm 8.5^{\circ}$ to $24.3^{\circ} \pm 6.1^{\circ}$ in the $S$ group and from $19.6^{\circ} \pm 11.2^{\circ}$ to $26.6^{\circ} \pm 8.5^{\circ}$ in the $T$ group. There were no significant differences in the changes of sagittal curves, coronal and sagittal balances at the 2-year follow-up and the number of fused segments and used screws between the two groups ( $p>0.05)$.

Conclusion: When conducting surgery for single thoracic AIS using pedicles screw instrumentation, two different instruments made of stainless steel and titanium alloy showed similar corrections for coronal and sagittal curves.

Key words: scoliosis, adolescent, pedicle screws, stainless steel, titanium

Received April 22, 2018 Revised June 24, 2018 Accepted August 13, 2018

¿Correspondence to: Dong-Ju Lim, M.D.

Department of Orthopedic Surgery, Inje University Sanggye Paik Hospital, 1342 Dongil-ro, Nowon-gu, Seoul 01757, Korea

TEL: +82-2-950-1290 FAX: +82-2-950-6342 E-mail: scd25@paik.ac.kr ORCID: https://orcid.org/0000-0002-3554-1734 
Sung-Soo Kim, et al.

\section{서 론}

특발성 척추 측만증의 수술적 치료는 척추 후방 기기의 발전과 그에 따른 여러 수술 술기의 개발로 급격한 변화와 발전을 이룩 하였다. 현재 척추 측만증 수술에서 널리 사용되고 있는 후방 기 기인 척추경 나사못을 모든 분절에 삽입하는 분절간 척추경 나 사못 고정술1)은 측만증의 교정을 향상시켰을 뿐만 아니라 강봉 회전술(rod derotation), ${ }^{23)}$ 척추 전이술(translation), ${ }^{4,5}$ 추체 회전술 (direct vertebral rotation) ${ }^{6.7)}$ 등의 여러 다양한 교정 방법을 적용할
수 있게 하였다.

척추에서 가장 튼튼한 구조물인 척추경을 고정 부위로 사용하 는 척추경 나사못은 1950 년대 Boucher ${ }^{8}$ 에 의해 처음 도입되었으 며 1960년대 Roy-Camille 등,10)에 의해 일반화되었다. 척추경 나 사못이 개발된 후 상당 기간 동안 스테인레스강(stainless steel)으 로 만들어진 기기가 사용되었으나 1990년대 이후에는 생체 적합 성(biocompatibility)이 뛰어나고 감염에도 강한 티타늄 합금(titanium alloy)으로 만들어진 기기 ${ }^{11-14}$ 가 널리 사용되었으며 현재에 는 스테인레스강으로 만들어진 척추경 나사못 기기는 사용되지
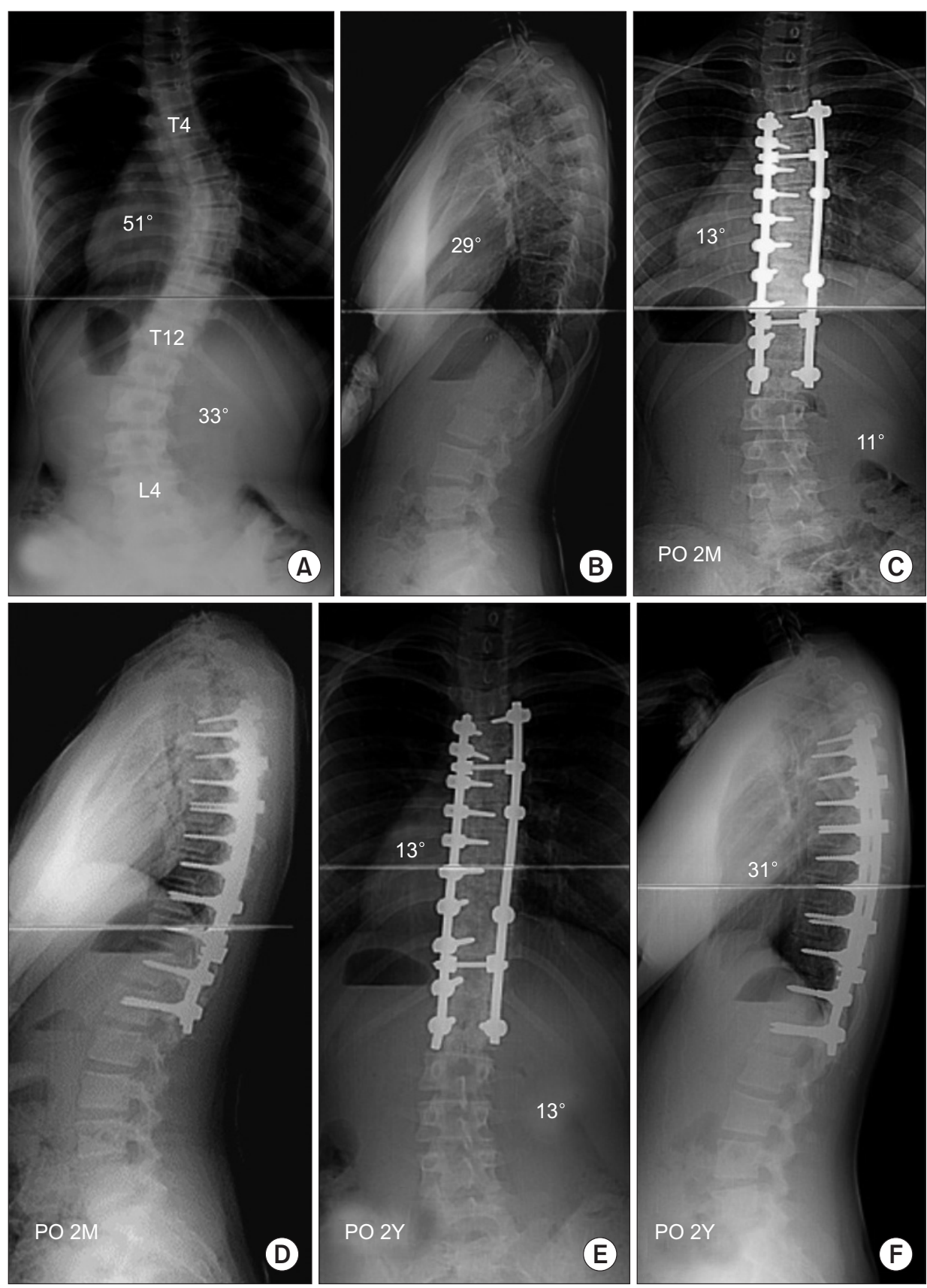

Figure 1. Thirteen-year-old girl with single thoracic curve. (A) Preoperative anterolateral radiograph showed the main thoracic curve of $51^{\circ}$ and the lumbar curve of $33^{\circ}$. (B) Preoperative lateral radiography. (C, D) Anteroposterior and lateral radiographs taken 2 months after surgery (PO 2M). The patient was treated with selective thoracic fusion from T4 to L1 using pedicle screw instruments made of stainless steel. The main thoracic curve was corrected to $13^{\circ}$ and the lumbar curve was spontaneously corrected to $11^{\circ}$. (E, F) Anteroposterior and lateral radiographs taken 2 years after surgery (PO 2Y). Coronal and sagittal alignments were well maintained during the followup. 
않고 있다. 하지만 티타늄 합금의 강도는 스테인레스강의 강도보 다 약한 것으로 알려져 ${ }^{15,16}$ 있으므로 기기를 이용하여 척추 변형을 교정하는 척추 측만증 수술에서 티타늄 합금 기기의 교정력이 스 테인레스강 기기에 비해 떨어질 수 있다는 생각을 쉽게 할 수 있다. 특히 기기의 구성물 중에서 강봉은 측만증을 교정하는 외부의 힘 이 직, 간접적으로 전달되므로 강봉의 강도는 척추 측만증의 교정 에 영향을 미칠 수 있을 것이라 생각되었다. 그리하여 저자들은 척 추 측만증 수술에서 두 기기의 차이를 확인해 보고자 하였다.

저자들이 조사한 바로는 특발성 척추 측만증 수술에서 저자들 이 사용하는 스테인레스강과 티타늄 합금으로 만들어진 기기나 강봉에 따라 측만증 교정을 비교하는 논문은 거의 없었다. 이에
저자들은 단일 흥추 청소년기 특발성 척추 측만증(single thoracic adolescent idiopathic scoliosis)의 수술적 치료로 척추경 나사못 고 정술을 시행한 경우 관상면과 시상면 만곡의 교정에 사용된 스테 인레스강과 티타늄 합금 기기나 강봉의 결과를 평가하고 비교해 보고자 하였다.

\section{대상 및 방법}

본 연구는 2001년 1월부터 2014년 12월까지 척추경 나사못 고정 술을 이용하여 선택적 흥추 유합(selective thoracic fusion)으로 치 료하고 최소 2 년 이상의 추시 관찰이 가능하였던 단일 흥추 청소
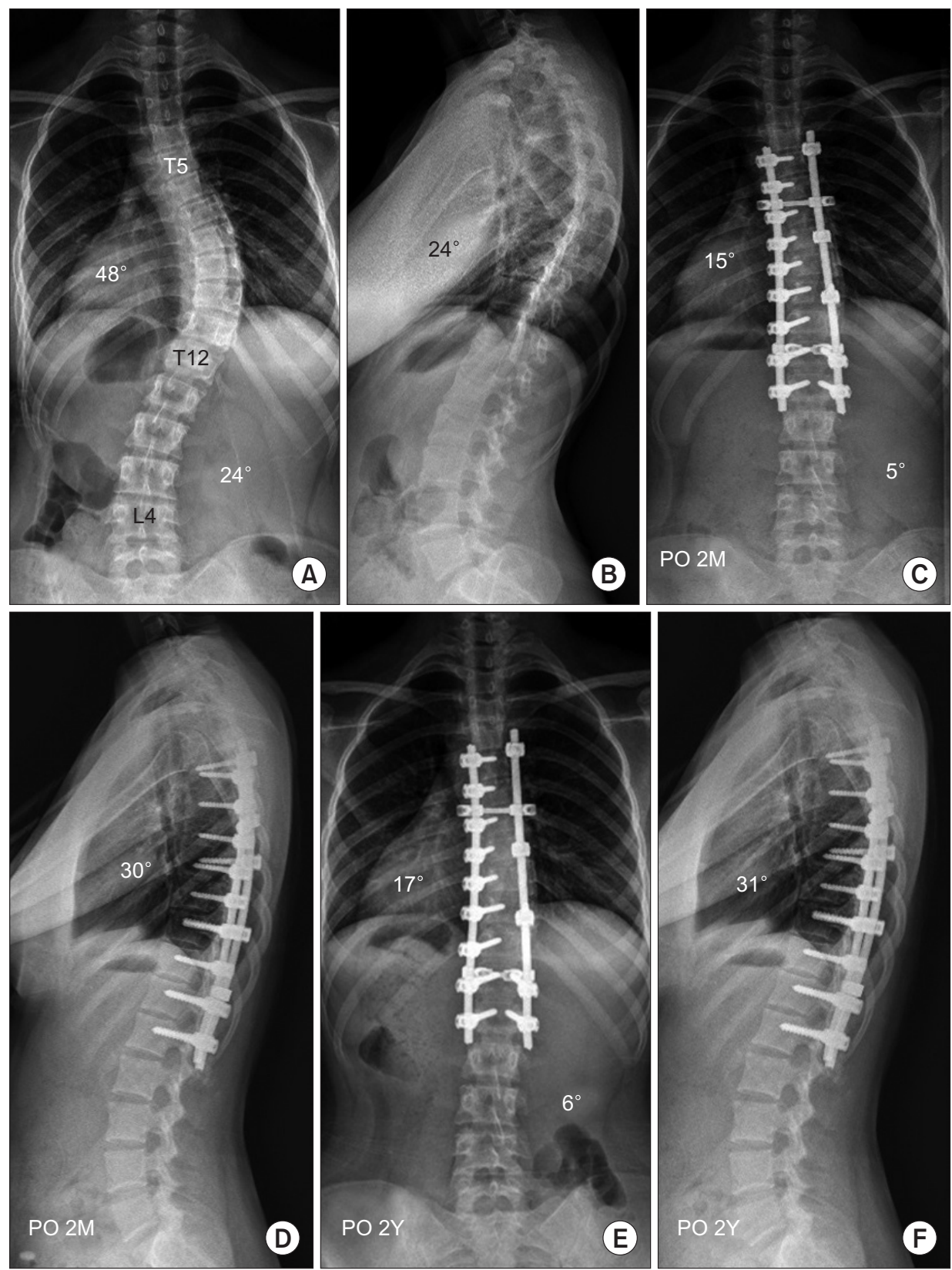

Figure 2. Fourteen-year-old girl with single thoracic curve. (A) Preoperative anterolateral radiograph showed the main thoracic curve of $48^{\circ}$ and the lumbar curve of $24^{\circ}$. (B) Preoperative lateral radiography. (C, D) Anteroposterior and lateral radiographs taken 2 months after surgery (PO 2M). The patient was treated with selective thoracic fusion from T5 to L1 using pedicle screw instruments made of titanium alloy. The main thoracic curve was corrected to $15^{\circ}$ and the lumbar curve was spontaneously corrected to $5^{\circ}$. (E, F) Anteroposterior and lateral radiographs taken 2 years after surgery (P0 2Y). Coronal and sagittal alignments were well maintained during the follow-up. 
Sung-Soo Kim, et al.

년기 특발성 척추 측만증 환자 141 명을 후향적으로 조사하였다. 주 흥추 만곡(main thoracic curve)이 $40^{\circ}-75^{\circ}$ 인 환자를 대상으로 하였고, 만곡의 교정은 강봉 회전술로 이루어졌으며 추체 회전술 을 병행하는 경우도 있었다. 그리고 추시 관찰에서 수술 부위 감 염증 또는 기기 실패(instrument failure)가 발생한 환자나 방사선 사진의 화질이 떨어져 방사선 계측을 할 수 없는 환자는 제외하 였다. 수술시 환자의 평균 나이는 14.1 \pm 2.0 세(11-20세)였으며 여 자가 132 명, 남자가 9 명이었다. 환자는 사용된 기기의 재료에 따 라 두 개의 군으로 나누어 $316 \mathrm{LVM}$ 스테인레스강으로 만들어진 기기를 사용한 경우를 S군(n=90, Fig. 1)으로, Ti-6Al-4V ELI (extra low interstitials) 티타늄 합금으로 만들어진 기기를 사용한 경우를 $\mathrm{T}$ 군(n=51, Fig. 2)으로 분류하였다. 스테인레스강 기기의 강봉 직 경은 $7 \mathrm{~mm}$ 였고, 티타늄 합금 기기의 강봉 직경은 $6.35 \mathrm{~mm}$ 또는 $6.0 \mathrm{~mm}$ 였다.

수술 전, 수술 후 6 개월 이내의 수술 직후 그리고 술 후 2년에 촬영한 기립성 전 척추 방사선 사진을 이용하여 만곡의 크기, 흥 추 후만과 요추 전만, 관상면과 시상면상 척추 균형을 측정하였 고, 또한 유합 분절 수와 사용된 척추경 나사못의 개수를 조사하 였다. 방사선 계측은 의료 영상 저장 전송 장치(picture archiving communication system)가 사용되어 이루어졌는데, 디지털 영상을 컴퓨터 프로그램인 M-view ${ }^{\mathrm{TM}} 5.4$ (Infinitt, Seoul, Korea)를 이용하 여 측정되었다.

만곡의 크기는 Cobb의 방법에 의하여 측정되었으며 흥추 후만 은 제 5 흥추의 상 골단판과 제 12 흥추의 하 골단판을, 요추 전만은 제 12 흥추의 상 골단판과 제 1 천추의 상 골단판을 이용하여 Cobb 의 방법으로 측정되었다. 관상면상 균형은 제7경추의 중심에서

Table 1. Basic Characteristics and Comparison of Two Groups

\begin{tabular}{|c|c|c|c|}
\hline Characteristic & $\begin{array}{l}\text { Stainless steel } \\
\text { group }(n=90)\end{array}$ & $\begin{array}{l}\text { Titanium alloy } \\
\text { group }(n=51)\end{array}$ & $p$-value \\
\hline Sex (female:male) & $84: 6$ & $48: 3$ & 1.00 \\
\hline Age (yr) & $14.0 \pm 2.0$ & $14.4 \pm 2.1$ & 0.14 \\
\hline \multicolumn{4}{|l|}{ Coronal curve $\left(^{\circ}\right)$} \\
\hline Upper thoracic curve & $28.5 \pm 9.9$ & $29.4 \pm 10.4$ & 0.69 \\
\hline Main thoracic curve & $51.3 \pm 8.4$ & $49.5 \pm 8.4$ & 0.18 \\
\hline Lumbar curve & $32.3 \pm 8.4$ & $30.3 \pm 8.9$ & 0.18 \\
\hline \multicolumn{4}{|l|}{ Sagittal curve $\left(^{\circ}\right)$} \\
\hline Thoracic kyphosis & $16.8 \pm 8.5$ & $19.6 \pm 11.2$ & 0.19 \\
\hline Lumbar lordosis & $49.5 \pm 10.4$ & $49.9 \pm 10.1$ & 0.81 \\
\hline \multicolumn{4}{|l|}{ Balance (mm) } \\
\hline Coronal balance & $9.8 \pm 8.0$ & $13.7 \pm 11.6$ & 0.10 \\
\hline Sagittal balance & $24.6 \pm 18.3$ & $20.1 \pm 14.2$ & 0.24 \\
\hline
\end{tabular}

Values are presented as number only or mean \pm standard deviation.
내린 수선(C7 plumb line)과 중심 천추 수직선(center sacral vertical line)과의 최단 거리로 측정하였고, 시상면상 균형은 제7경추에서 내린 수선과 제 1 천추체의 후상단면과의 최단 거리로 측정하였다.

통계적 처리는 MedCalc ver. 17.6 (MedCalc Software, Mariakerke, Belgium)을 사용하여 성별을 제외한 모든 측정값 에 대한 두 군 간 비교는 모수적 방법(parametric method)으로 Student T 검사를, 비모수적 방법(nonparametric method)으로 Mann-Whitney 검사를 이용하여 시행하였다. 그리고 성별에 대한 두 군 간의 비교는 Fisher's exact 검사로 이루어졌으며, 각 각의 군에서 술 전과 술 후의 비교는 대응 표본 $\mathrm{T}$ 검사(paired $\mathrm{T}$ test)로 이루어졌다. $\mathrm{p}$ 값이 0.05 보다 작은 경우 유의한 것으로 평 가하였다.

\section{결 과}

$\mathrm{S}$ 군은 여자 84 명, 남자 6 명으로 수술시 평균 나이는 $14.0 \pm 2.0$ 세이

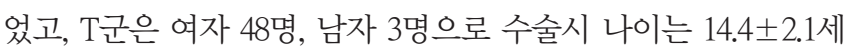
이었다. 술 전 S군과 T군의 상부 흥추, 주(하부) 흥추 및 요추 만곡 의 크기와 흥추 후만, 요추 전만, 시상면과 관상면상 균형은 Table 1 에 기술하였다. 성별, 나이, 수술 전 만곡의 모든 측정값은 두 군 간에 통계적으로 유의한 차이는 없었다( $\mathrm{p}>0.05)$.

$\mathrm{S}$ 군의 유합 분절 수는 $8.9 \pm 1.1$ 분절, 사용된 척추경 나사못은 $14.0 \pm 2.0$ 개였으며, T군의 유합 분절 수는 $8.7 \pm 1.0$ 분절, 사용된 척 추경 나사못은 $14.4 \pm 1.9$ 개였다. 유합 분절 수 및 사용된 척추경 나사못의 개수에는 두 군 간에 유의한 차이는 없었다 $(\mathrm{p}>0.05)$.

$\mathrm{S}$ 군에서 술 전 $51.3^{\circ} \pm 8.4^{\circ}$ 의 주 흥추 만곡은 수술 직후 $16.2^{\circ} \pm$ $6.6^{\circ}$ 로 평균 $68.4 \%$ 의 교정을 보였고 술 후 2 년 추시에서 $19.0^{\circ} \pm$ $7.6^{\circ}$ 로 술 전 대비 평균 $63.1 \%$ 의 교정을 보였다. $\mathrm{S}$ 군의 술 전 $32.2^{\circ}$ $\pm 8.4^{\circ}$ 의 요추 만곡은 수술 직후 $10.8^{\circ} \pm 7.7^{\circ}$ (평균 $68.5 \%$ 교정) 로, 술 후 2 년 추시에서 $12.7^{\circ} \pm 8.2^{\circ}$ (평균 $62.9 \%$ 교정)로 감소 하였다. T군에서 술 전 $49.5^{\circ} \pm 8.4^{\circ}$ 의 주 흥추 만곡은 수술 직 후 $16.0^{\circ} \pm 6.6^{\circ}$ 로 평균 $67.6 \%$ 의 교정을 보였고 술 후 2 년 추시에 서 $18.8^{\circ} \pm 7.4^{\circ}$ 로 술 전 대비 평균 $62.2 \%$ 의 교정을 보였다. T군 의 술 전 $30.3^{\circ} \pm 8.9^{\circ}$ 의 요추 만곡은 수술 직후 $9.9^{\circ} \pm 5.3^{\circ}$ (평균 $67.0 \%$ 교정)로 술 후 2년 추시에서 $11.3^{\circ} \pm 5.4^{\circ}$ (평균 $63.3 \%$ 교 정)로 감소하였다. 수술 직후와 술 후 2년에서 주 흥추 만곡 및 요추 만곡의 크기와 교정률에는 두 군 간에 유의한 차이가 없 었다(p>0.05, Table 2). 또한 상부 흥추 만곡의 크기와 교정률도 수술 직후 및 술 후 2 년 추시에서 두 군 간에 유의한 차이는 없 었다( $\mathrm{p}>0.05$, Table 2).

$\mathrm{S}$ 군의 흥추 후만은 술 전 $16.8^{\circ} \pm 8.5^{\circ}$ 에서 술 후 2 년에는 $24.3^{\circ} \pm$ $6.1^{\circ}$ 로 평균 $7.5^{\circ}$ 증가되었고, $\mathrm{T}$ 군의 흥추 후만은 술 전 $19.6^{\circ} \pm$ $11.2^{\circ}$ 에서 술 후 2 년에는 $26.6^{\circ} \pm 8.5^{\circ}$ 로 평균 $7.0^{\circ}$ 증가되어 두 군 모 두 술 전과 비교하여 술 후 통계적으로 의미 있는 증가를 보였 
다 $(\mathrm{p}<0.05)$. 수술 직후와 술 후 2 년의 흥추 후만 정도와 술 전 대 비 증가량에서 두 군 간에 유의한 차이는 없었다 $(\mathrm{p}>0.05$, Table 2). 요추 전만과 시상면상 균형에도 수술 직후와 수술 2 년째 두 군 간에 유의한 차이는 없었다. 관상면상 균형은 수술 직후 $\mathrm{S}$ 군 은 $10.2 \pm 8.9 \mathrm{~mm}$, T군은 $14.7 \pm 12.0 \mathrm{~mm}$ 로 두 군 간에 유의한 차이 는 있었으나 $(\mathrm{p}<0.05)$, 수술 2년째 추시에서 $\mathrm{S}$ 군은 $8.9 \pm 7.2 \mathrm{~mm}, \mathrm{~T}$ 군은 $11.7 \pm 9.2 \mathrm{~mm}$ 로 두 군 간에 유의한 차이는 없었다 $(\mathrm{p}>0.05$, Table 2).

\section{고 찰}

척추경 나사못은 척추에 제일 강한 구조물인 척추경 나사못을 고 정 부위로 사용하기 때문에 다른 후방 기기들보다 향상된 고정력 을 보여 주었으며, 이를 각 분절마다 삽입하는 분절 간 척추경 나 사못 고정술은 고정력을 최대한 증가시켜 척추 측만증 수술에 있 어 우수한 교정을 보여 주었을 뿐만 아니라 3차원적 교정을 가능 하게 하였다. ${ }^{17,17,18}$ 처음 척추경 나사못이 도입되고 상당 기간 동 안에는 스테인레스강으로 만들어진 기기가 사용되었으나 이후에 는 생체 적합성이 더욱 뛰어난 티타늄 합금으로 만들어진 기기가 생산되고 이것이 널리 보급되면서 현재에는 스테인레스강의 척 추경 나사못 기기를 찾아볼 수 없는 실정이다.

스테인레스강은 $50 \%$ 이상의 철(iron)과 $10.5 \%$ 이상의 크롬 (chromium)으로 구성된 금속 합금을 말하며, 여기에 니켈(nickel) 이 포함된 것을 오스테나이트계(austenitic) 스테인레스강이라 고 한다. 척추를 비롯한 정형외과 영역에서 인체에 사용되는 $316 \mathrm{LVM}$ 은 오스테나이트계 스테인레스강의 일종으로 앞에서
언급된 구성물에 몰리브덴(molybdenum)을 첨가하고 탄소 함유 량을 낮추면서 특수한 공정을 통해 불순물을 최소화한 것이다. $316 \mathrm{LVM}$ 스테인레스강으로 만들어진 척추경 나사못 기기는 강도 가 뛰어나지만, 컴퓨터 단층촬영 영상(computed tomography, CT) 이나 자기공명영상(magnetic resonance imaging, MRI)에서 인공물 (artifact)로 인해 영상 촬영이 제한될 뿐만 아니라 부식(corrosion) 이나 금속 감수성(metal sensitivity)의 우려가 있고 감염에 상대적 으로 취약한 문제점이 있었다. ${ }^{12-14,19,20)}$ 이러한 스테인레스강의 문 제점은 티타늄 합금으로 극복될 수 있었다. 티타늄에 약 $6 \%$ 의 알 루미늄(aluminum)과 4\%의 반듐(vanadium)을 혼합한 티타늄 합금 인 Ti-6Al-4V가 인체에 사용되었으며, 여기에 철, 산소, 탄소, 질 소의 함유량을 낮춘 Ti-6Al-4V ELI가 현재에는 사용되고 있다. 티타늄 합금은 부식에 저항성이 높고 알레르기 반응이 없으며 생 체 적합성이 뛰어났다. ${ }^{11)}$ 또한 스테인레스강과 비교하여 CT와 $\mathrm{MRI}$ 에서도 인공물로 인한 제한이 적었다. ${ }^{20)}$

실제 본 연구에서 2008년까지는 티타늄 합금 기기보다는 스테 인레스강 기기를 이용하여 수술을 시행한 환자가 더 많았으나 2009년에는 티타늄 합금 기기가 스테인레스강 기기보다는 자주 사용되었고 2010년 이후에는 티타늄 합금 기기만 이용되었다.

티타늄 합금 기기의 여러 장점에도 불구하고 동일한 디자인과 크기의 스테인레스강 기기와 비교하여 강도가 약한 것으로 알려 져 있고, ${ }^{16)}$ 조형된(contoured) 티타늄 합금 강봉도 조형된 스테인 레스강 강봉보다 피로 강도(fatigue strength)가 의미 있게 낮은 것 으로 알려져 있다. ${ }^{15)}$ 척추 측만증의 교정률은 기기의 강도에 영 향을 받으므로 티타늄 합금 기기의 측만증 교정률이 스테인레스 강 기기의 교정률보다 떨어질 것이라 생각할 수 있을 것이다. 그

Table 2. The Preoperative and Postoperative Radiographic Measurements and Comparison of Two Groups

\begin{tabular}{|c|c|c|c|c|c|c|c|c|}
\hline \multirow{2}{*}{ Variable } & \multicolumn{3}{|c|}{ Stainless steel group $(n=90)$} & \multicolumn{3}{|c|}{ Titanium alloy group $(n=51)$} & \multicolumn{2}{|c|}{$p$-value } \\
\hline & Preoperative & Early PO & 2Y PO & Preoperative & Early PO & 2Y PO & Early PO & $2 Y \mathrm{PO}$ \\
\hline Upper thoracic curve $\left(^{\circ}\right)$ & $28.5 \pm 9.9$ & $16.5 \pm 6.5$ & $17.1 \pm 7.8$ & $29.4 \pm 10.4$ & $17.5 \pm 8.6$ & $18.0 \pm 8.3$ & 0.44 & 0.55 \\
\hline Correction rate* $(\%)$ & & $41.1 \pm 18.8$ & $40.2 \pm 20.6$ & & $41.9 \pm 18.2$ & $39.9 \pm 18.1$ & 0.80 & 0.94 \\
\hline Main thoracic curve $\left(^{\circ}\right)$ & $51.3 \pm 8.4$ & $16.2 \pm 6.6$ & $19.0 \pm 7.6$ & $49.5 \pm 8.4$ & $16.0 \pm 6.6$ & $18.8 \pm 7.4$ & 0.88 & 0.85 \\
\hline Correction rate* $(\%)$ & & $68.4 \pm 11.6$ & $63.1 \pm 13.0$ & & $67.6 \pm 12.6$ & $62.2 \pm 13.7$ & 0.71 & 0.69 \\
\hline Lumbar curve $\left(^{\circ}\right)$ & $32.2 \pm 8.4$ & $10.8 \pm 7.7$ & $12.7 \pm 8.2$ & $30.3 \pm 8.9$ & $9.9 \pm 5.3$ & $11.3 \pm 5.4$ & 0.85 & 0.39 \\
\hline 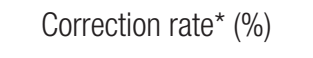 & & $68.5 \pm 18.7$ & $62.9 \pm 18.9$ & & $67.0 \pm 15.6$ & $63.3 \pm 13.5$ & 0.58 & 0.88 \\
\hline Thoracic kyphosis $\left({ }^{\circ}\right)$ & $16.8 \pm 8.5$ & $20.9 \pm 6.1$ & $24.3 \pm 6.1$ & $19.6 \pm 11.2$ & $22.6 \pm 8.6$ & $26.6 \pm 8.5$ & 0.17 & 0.13 \\
\hline Increase ${ }^{\star}\left({ }^{\circ}\right)$ & & $4.2 \pm 7.8$ & $7.5 \pm 7.5$ & & $3.0 \pm 7.7$ & $7.0 \pm 9.2$ & 0.31 & 0.71 \\
\hline Lumbar lordosis $\left({ }^{\circ}\right)$ & $49.5 \pm 10.4$ & $47.0 \pm 11.7$ & $51.6 \pm 10.4$ & $49.9 \pm 10.1$ & $48.7 \pm 12.9$ & $50.5 \pm 11.1$ & 0.52 & 0.55 \\
\hline Coronal balance $(\mathrm{mm})$ & $9.8 \pm 8.0$ & $10.2 \pm 8.9$ & $8.9 \pm 7.2$ & $13.7 \pm 11.6$ & $14.7 \pm 12.0$ & $11.7 \pm 9.2$ & 0.03 & 0.10 \\
\hline Sagittal balance (mm) & $24.6 \pm 18.3$ & $20.6 \pm 17.2$ & $21.2 \pm 16.2$ & $20.1 \pm 14.2$ & $23.1 \pm 20.1$ & $19.3 \pm 16.7$ & 0.44 & 0.45 \\
\hline
\end{tabular}

Values are presented as mean \pm standard deviation. *The figures were the mean values calculated from comparison of the preoperative values. Early PO, early postoperative; 2 Y P0, 2 years postoperative. 
Sung-Soo Kim, et al.

리하여 저자들은 이러한 두 개의 재료로 만들어진 척추경 나사 못 기기를 이용하여 특발성 척추 측만증 수술을 시행하면서 서로 다른 기기가 변형 교정에 미치는 영향을 비교 평가해 보고자 하 였다. 저자들이 사용한 두 기구 중에서 특히 차이를 보이는 부분 은 강봉이었다. 스테인레스강 강봉은 직경이 $7 \mathrm{~mm}$ 이고 기기 조 작 시 미끄럼을 방지하기 위해 겉면에 빗금이 있어 거친(knurled surface) 반면에 티타늄 합금 강봉은 직경이 $6.35 \mathrm{~mm}$ 또는 $6.0 \mathrm{~mm}$ 이며 겉면에 빗금은 없고 매끈하였다(smooth surface). 강봉 기기 의 재료와 직경의 차이로 인해 본 연구에서 사용된 스테인레스강 강봉의 강도는 티타늄 합금 강봉의 강도보다 높다는 점과 강봉 감염술이나 척추 전이술에서 측만증 교정을 위한 외력이 직접적 으로 강봉에 가해지는 점을 고려해 볼 때 이러한 두 기기의 강봉 차이는 척추 변형의 교정에 영향을 주어 다른 결과를 나타낼 수 도 있을 것으로 저자들은 생각하고 본 연구를 시행하였지만 의미 있는 차이를 발견할 수 없었다. 현재까지 측만증을 교정하는 데 에 필요한 적정한 강봉의 강도에 대해서는 알려져 있는 바는 없 다.

Okada 등른 척추경 나사못 고정술을 시행하고 최소 2년 추시 한 65 명의 청소년기 특발성 척추 측만증 환자를 스테인레스강 기 기(27명)와 티타늄 합금 기기(38명)로 나누어 비교하여 보고하였 다. 이 보고에서 사용된 강봉의 직경은 두 기기 모두 $5.5 \mathrm{~mm}$ 였고, 수술 직후와 최종 추시에서 주 만곡의 크기와 교정률, 흥추 후만 및 관상면과 시상면의 균형은 두 기기 간에 차이는 없었다. 그들 의 연구 결과는 저자들의 이번 연구 결과와 비슷한 결과를 보여 주고 있으나 두 연구는 여러모로 차이점이 있다. 먼저 저자들이 사용한 스테인레스강 기기의 강봉 직경 $(7 \mathrm{~mm})$ 은 티타늄 합금의 강봉 직경 6.35 또는 $6.0 \mathrm{~mm})$ 보다 굵기 때문에 두 기기의 강봉 강 도 차이는 Okada 등리 이 사용한 두 기기의 강봉 강도 차이보다 더 크다고 할 수 있다. 그리고 Okada 등 ${ }^{21}$ 은 단일 흥추 만곡뿐만 아 니라 이중 흥추 만곡, 이중 주 만곡, 삼중 주 만곡, 흥요추 만곡 등 청소년기 특발성 척추 측만증의 모든 만곡을 포함하여 주 만곡의 크기와 교정률을 비교하였는데 동일한 기기를 사용하더라도 만 곡의 형태에 따라 수술 후 주 만곡의 크기와 교정률이 달라질 수 점을 고려한다면 두 군 간의 비교에 제한이 있을 것으로 판단된 다. 또한 보상 만곡에 대한 자료나 비교가 없고 연구에서 가장 환 자 수가 많은 단일 흥추 만곡이 총 25명으로 두 기기를 비교하기 에는 대상 환자군이 적은 문제점이 있었다. 이에 반해 저자들은 $40^{\circ}-75^{\circ}$ 의 주 흥추 만곡을 가진 141 명의 환자를 대상으로 연구를 시행하여 동일한 만곡 형태를 가진 충분한 환자군이 포함된 것으 로 Okada 등리 의 연구와 차이가 있다.

최근 Di Silvestre 등른 척추경 나사못 고정술만을 시행한 143 명의 청소년기 특발성 척추 측만증을 기기의 재료와 기기 밀도 (implant density)에 따라 4 개의 군으로 나누었다. 즉 기기의 재료 는 스테인레스강과 티타늄 합금으로 분류하였고 나사못(또는 기
기) 밀도는 60\% 미만을 비분절(non-segmental) 고정으로, $60 \%$ 이 상을 분절(segmental) 고정으로 정의하여 분류하였다. 여기에서 나사못 밀도는 사용된 척추경 나사못 개수를 유합 범위에서의 척 추경 개수로 나누어 백분율화한 값이다. 23,24$)$ 그들이 분류한 4개의 군에서 티타늄 합금 기기의 비분절 고정에서 교정률이 유의하게 낮았고 나머지 3군에서는 차이가 없었다고 보고하였다.2) 저자들 의 연구 결과는 Di Silvestre 등리이 분절 고정으로 분류한 환자에 서의 연구 결과와 일치하였다. 본 연구에서 $\mathrm{S}$ 군의 나사못 밀도는 평균 70\%, T군의 나사못 밀도는 평균 74\%로 측정되어, 대부분의 환자에서 $60 \%$ 이상으로 Di Silvestre 등 ${ }^{22}$ 의 분류로는 분절 고정에 해당되었다.

이번 연구에서 청소년기 특발성 흥추 측만증의 관상면상 교정 률은 스테인레스강과 티타늄 합금 기기의 유의한 차이는 보이지 않았다. 더욱이 유합하지 않은 상부 흥추와 요추 만곡의 교정률, 흥추 후만의 정도와 변화량, 요추 전만과 관상면 및 시상면상의 균형에도 두 기기에서 유의한 차이는 없었다. 이러한 결과는 스 테인레스강과 티타늄 합금으로 만들어진 기기와 강봉으로 청소 년기 흥추 측만증 교정에서 비슷한 결과를 얻는다는 것을 알 수 있었다.

척추경 나사못 고정술에서 술 후 흥추 후만은 술 전과 비교 하여 감소하거나 변화가 없다는 보고 ${ }^{22,25)}$ 가 있으나 본 연구에서 흥추부 후만은 두 군 모두에서 술 후 의미 있게 증가되었다. 이 는 강봉 회전술 이후에 정상적인 시상 만곡을 형성하도록 강봉 을 적절히 조형한다면 스테인레스강이나 티타늄 강봉에 상관 없이 흥추 후만을 회복시킬 수 있다는 것을 보여주는 것이라고 판단된다.

본 연구는 후향적 연구라는 제한점이 있다. 하지만 스테인레 스강으로 만들어진 척추경 나사못을 현재는 사용할 수 없으므 로 전향적 연구를 할 수 없다는 실정을 감안한다면 의의가 있 다고 할 수 있다. 또한 방사선적 결과만을 조사하여 설문지 등 을 이용한 임상적 측면을 고려하지 않은 문제점도 있다. 그리고 최근 사용이 증가되고 있는 코발트-크로뮴(cobalt-chromium) 강봉 ${ }^{26}$ 에 연구에 포함하지 않은 제한점도 있으나 이는 차후 증 례가 늘어난다면 향후 연구 주제가 될 수 있을 것으로 판단된 다.

\section{결 론}

척추경 나사못을 이용한 단일 흥추 청소년기 특발성 척추 측만증 수술에서 스테인레스강과 티타늄 합금 기기와 강봉은 관상면과 시상면에서 의미 있는 차이 없이 비슷한 교정을 보였다. 그러므 로 두 개의 기기와 강봉의 강도 차이에 따라 교정률의 차이가 있 을 수 있을 것이라는 저자들의 가설은 이번 연구로 잘못된 것임 을 알 수 있었다. 


\section{CONFLICTS OF INTEREST}

The authors have nothing to disclose.

\section{REFERENCES}

1. Suk SI, Lee CK, Kim WJ, Chung YJ, Park YB. Segmental pedicle screw fixation in the treatment of thoracic idiopathic scoliosis. Spine (Phila Pa 1976). 1995;20:1399-405.

2. Cotrel Y, Dubousset J, Guillaumat M. New universal instrumentation in spinal surgery. Clin Orthop Relat Res. 1988;227:10-23.

3. Suk SI, Kim JH, Cho KJ, Kim SS, Lee JJ, Han YT. Is anterior release necessary in severe scoliosis treated by posterior segmental pedicle screw fixation? Eur Spine J. 2007;16:1359-65.

4. Muschik M, Schlenzka D, Robinson PN, Kupferschmidt C. Dorsal instrumentation for idiopathic adolescent thoracic scoliosis: rod rotation versus translation. Eur Spine J. 1999;8:93-9.

5. Webb JK, Burwell RG, Cole AA, Lieberman I. Posterior instrumentation in scoliosis. Eur Spine J. 1995;4:2-5.

6. Suk SI, Kim JH, Kim SS, Lim DJ. Pedicle screw instrumentation in adolescent idiopathic scoliosis (AIS). Eur Spine J. 2012;21:13-22.

7. Kim SS, Kim JH, Suk SI. Effect of direct vertebral rotation on the uninstrumented lumbar curve in thoracic adolescent idiopathic scoliosis. Asian Spine J. 2017;11:127-37.

8. Boucher HH. A method of spinal fusion. J Bone Joint Surg Br. 1959;41:248-59.

9. Roy-Camille R, Saillant G, Mazel C. Internal fixation of the lumbar spine with pedicle screw plating. Clin Orthop Relat Res. 1986;203:7-17.

10. Roy-Camille R, Saillant G, Mazel C. Plating of thoracic, thoracolumbar, and lumbar injuries with pedicle screw plates. Orthop Clin North Am. 1986;17:147-59.

11. Binyamin G, Shafi BM, Mery CM. Biomaterials: a primer for surgeons. Semin Pediatr Surg. 2006;15:276-83.

12. Di Silvestre M, Bakaloudis G, Lolli F, Giacomini S. Late-developing infection following posterior fusion for adolescent idiopathic scoliosis. Eur Spine J. 2011;20:S121-7.

13. Dick JC, Bourgeault CA. Notch sensitivity of titanium alloy, commercially pure titanium, and stainless steel spinal implants. Spine (Phila Pa 1976). 2001;26:1668-72.
14. Gotman I. Characteristics of metals used in implants. J Endourol. 1997;11:383-9.

15. Lindsey C, Deviren V, Xu Z, Yeh RF, Puttlitz CM. The effects of rod contouring on spinal construct fatigue strength. Spine (Phila Pa 1976). 2006;31:1680-7.

16. Pienkowski D, Stephens GC, Doers TM, Hamilton DM. Multicycle mechanical performance of titanium and stainless steel transpedicular spine implants. Spine (Phila Pa 1976). 1998;23:782-8.

17. Di Silvestre M, Lolli F, Bakaloudis G, Maredi E, Vommaro F, Pastorelli F. Apical vertebral derotation in the posterior treatment of adolescent idiopathic scoliosis: myth or reality? Eur Spine J. 2013;22:313-23.

18. Fu G, Kawakami N, Goto M, Tsuji T, Ohara T, Imagama S. Comparison of vertebral rotation corrected by different techniques and anchors in surgical treatment of adolescent thoracic idiopathic scoliosis. J Spinal Disord Tech. 2009;22:182-9.

19. Kim YJ, Kassab F, Berven SH, et al. Serum levels of nickel and chromium after instrumented posterior spinal arthrodesis. Spine (Phila Pa 1976). 2005;30:923-6.

20. Knott PT, Mardjetko SM, Kim RH, et al. A comparison of magnetic and radiographic imaging artifact after using three types of metal rods: stainless steel, titanium, and vitallium. Spine J. 2010;10:789-94.

21. Okada E, Watanabe K, Hosogane N, et al. Comparison of stainless steel and titanium alloy instruments in posterior correction and fusion surgery for adolescent idiopathic scoliosis-prospective cohort study with minimum 2-year follow-up. J Med Biol Eng. 2013;33:325-9.

22. Di Silvestre M, Bakaloudis G, Ruosi C, et al. Segmental vs non-segmental thoracic pedicle screws constructs in adolescent idiopathic scoliosis: Is there any implant alloy effect? Eur Spine J. 2017;26:533-8.

23. Clements DH, Betz RR, Newton PO, Rohmiller M, Marks MC, Bastrom T. Correlation of scoliosis curve correction with the number and type of fixation anchors. Spine (Phila Pa 1976). 2009;34:2147-50.

24. Gebhart S, Alton TB, Bompadre V, Krengel WF. Do anchor density or pedicle screw density correlate with short-term outcome measures in adolescent idiopathic scoliosis surgery? Spine (Phila Pa 1976). 2014;39:E104-10.

25. Quan GM, Gibson MJ. Correction of main thoracic adolescent idiopathic scoliosis using pedicle screw instrumentation: 
Sung-Soo Kim, et al.

does higher implant density improve correction? Spine (Phila Pa 1976). 2010;35:562-7.

26. Lamerain M, Bachy M, Delpont M, Kabbaj R, Mary P, Vialle
R. CoCr rods provide better frontal correction of adolescent idiopathic scoliosis treated by all-pedicle screw fixation. Eur Spine J. 2014;23:1190-6. 


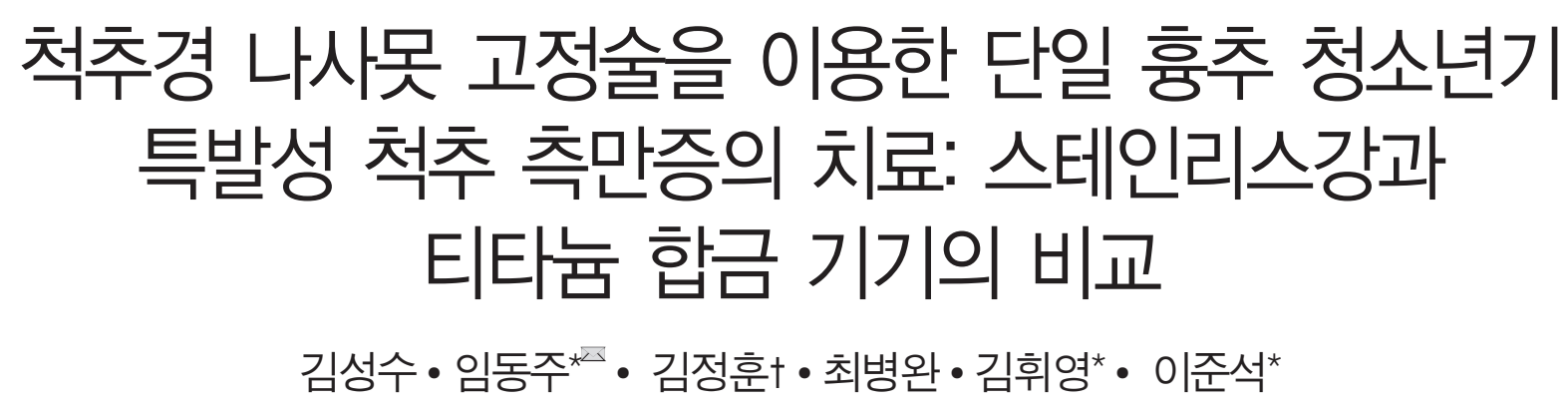

인제대학교 해운대백병원 정형외과, ${ }^{*}$ 인제대학교 상계백병원 정형외과, †인제대학교 일산백병원 정형외과

목적: 단일 흥추 청소년기 특발성 척추 측만증의 수술적 치료로 척추경 나사못 고정술이 시행된 경우에 서로 다른 재질인 스테인레 스강과 티타늄 합금 기기의 결과를 비교해 보고자 하였다.

대상 및 방법: 척추경 나사못 고정술과 선택적 흥추 유합술을 이용하여 수술을 시행하고 최소 2년 이상 추시가 가능하였던 단일 흥 추 청소년기 특발성 척추 측만증 환자 141 명을 후향적으로 조사하였다. 주 흥추 만곡이 $40^{\circ}-75^{\circ}$ 인 환자를 대상으로 하였으며, 기 기의 재질에 따라 스테인레스강 기기가 사용된 경우는 S군(90명)으로, 티타늄 합금 기기가 사용된 경우는 T군(51명)으로 나누었다. S 군의 강봉 직경은 $7.0 \mathrm{~mm}$ 였고 T군의 강봉 직경은 $6.35 \mathrm{~mm}$ 나 $6.0 \mathrm{~mm}$ 였다. 수술 전, 수술 직후와 술 후 2 년에 촬영한 기립성 전 척 추 방사선 사진을 이용하여 방사선적 측정을 시행하였다. 술 전 관상면과 시상면상 만곡의 측정값에서 두 군 간에 유의한 차이는 없었 다.

결과: $\mathrm{S}$ 군에서 술 전 $51.3^{\circ} \pm 8.4^{\circ}$ 의 주 흥추 만곡은 술 후 2 년에 $19.0^{\circ} \pm 7.6^{\circ}$ (63.1\% 교정)로 감소되었고, 술 전 $32.3^{\circ} \pm$ $8.4^{\circ}$ 의 요추 만곡은 술 후 2 년에 $12.7^{\circ} \pm 8.2^{\circ}$ ( $62.9 \%$ 교정)로 감소되었다. T군에서는 술 전 $49.5^{\circ} \pm 8.4^{\circ}$ 의 주 흥추 만곡과 $30.3^{\circ} \pm 8.9^{\circ}$ 의 요추 만곡은 술 후 2 년에 각각 $18.8^{\circ} \pm 7.4^{\circ}$ (62.2\% 교정)와 $11.3^{\circ} \pm 5.4^{\circ}$ (63.3\% 교정)로 감소되었다. 관상면 상 만곡의 교정은 두 군 간에 통계적으로 유의한 차이는 없었다 $(\mathrm{p}>0.05)$. 흥추 후만은 $\mathrm{S}$ 군에서 술 전 $16.8^{\circ} \pm 8.5^{\circ}$ 에서 술 후 2 년 에 $24.3^{\circ} \pm 6.1^{\circ}$ 로, T군에서는 $19.6^{\circ} \pm 11.2^{\circ}$ 에서 $26.6^{\circ} \pm 8.5^{\circ}$ 로 증가되었다. 유합 분절수, 사용된 척추경 나사못의 개수 및 술 후 2 년의 흥추 후만, 요추 전만, 관상면과 시상면 균형에도 두 군 간에 유의한 차이는 없었다( $(p>0.05)$.

결론: 척추경 나사못 고정술을 이용한 단일 흥추 청소년기 특발성 척추 측만증 수술에서 스테인레스강과 티타늄 합금 기기와 강봉은 관상면과 시상면에서 의미 있는 차이 없이 비슷한 교정을 보였다.

색인단어: 측만증, 청소년, 척추경 나사못, 스테인레스강, 티타늄

접수일 2018년 4월 22일 수정일 2018년 6월 24일 게재확정일 2018년 8월 13일

책임저자 임동주

01757, 서울시 노원구 동일로 1342 인제대학교 상계백병원 정형외과

TEL 02-950-1290, FAX 02-950-6342, E-mail scd25@paik.ac.kr, ORCID https://orcid.org/0000-0002-3554-1734 